Annals of Plant and Soil Research 23(3): 334-340 (2021)

https://doi.org/10.47815/apsr.2021.10080

\title{
Correlation of stress indices with yield parameters in wild chickpea (Cicer arietinum L.) accessions under irrigated and rainfed conditions
}

\section{*1'NORAH JOHAL, ${ }^{2}$ JAGMEET KAUR, ${ }^{3}$ ASHUTOSH KUSHWAH AND ${ }^{4}$ SARVJEET SINGH}

\author{
${ }^{1}$ Department of Botany, ${ }^{2,3,4}$ Department of Plant Breeding \& Genetics, Punjab Agricultural University, Ludhiana \\ Received: April, 2021: Revised accepted: June, 2021
}

\begin{abstract}
Six wild chickpea accessions were procured during Rabi seasons 2015-16 and 2016-17 seasons at Punjab Agricultural University, Ludhianato record morpho-physiological parameters and yield components at pod initiation stage. The experiment was carried out in randomized block design with two treatments irrigated and rainfed each with three replicates. Results indicated a significant decrease in the specific leaf weight $(S L W)$, photosynthetic rate (PR) and relative water content (RWC) under rainfed conditions in wild chickpea accessions. Wild accessions C judaicum 17148 (29.5\%) and C pinnatifidum212 (31.0\%)displayed their resistance towards water scarcity by maintaining high relative water content that depicted negative correlation with membrane damage ( $r=-0.98)$. The membrane damage showedan inversely proportional relationship ( $r=-$ 0.69) withseed weight, a yield component under rainfed conditions evidencing the requirement of water at pod filling stage.
\end{abstract}

Keywords: Wild chickpea, rainfed condition, restricted moisture, physiology and yield.

\section{INTRODUCTION}

Chickpea(Cicer arietinum L.) production is very crucial for India as is evident from the fact that India accounts for $75 \%$ of the total world production solely (Ahsan et al. 2018). The gross production of chickpea is mostly in the rainfed areas of Maharashtra, Rajasthan, Gujrat faces where the problem of terminal drought stress is persistent. Terminal drought affects pod filling stage which leads to decline in the final yield of the plant. The pod initiation stage requires the synthesis of de novophoto synthates stored in the seeds that are altered under drought stress which inactivates various enzymatic processes responsible for the synthesis of the same (Hamidouet al. 2013).Low genotypic variance and instability in maintaining stable and consistent environment for screening conditions paves hindrance for breeding and selecting new genotypes conferring high yield potential. Despite the hurdles, it is imperative to identify genotypes or lines that will be detrimental in producing new hybrids possessing yield potential and resistance to terminal drought stress. Domesticated varieties that are being used on economical purposes serve for high yields but for short duration. With the tenure, the tolerance capacity decreases on account of rapidly changing scenario and become vulnerable to biotic and abiotic stresses. As a result of the domestication in the cultivated types to inculcate higher productivity there is a loss of valuable genes relating to biotic and abiotic stress tolerance, thus leading to a more general narrowing down of their genetic base that acts as the key factor contributing to the low yield.

The wild species that had survived through ages without any domestication have selective and desirable genes. These species might not be having a high yield, as their priority remains survival capacity rather than yield. The present study was conducted on wild accessions at pod initiation stage and at maturity to screen their vulnerability regarding the water deficit conditions which might act as progenitors for producing recombinant lines in forthcoming schema.

\section{MATERIAL AND METHODS}

Six desi wild accessions ( $3 m^{*} 3$ rows) were subjected to irrigated (lined with water channels on two sides) and rainfed (no irrigation) treatments in the experimental area of pulses section, Punjab Agricultural University, Ludhiana situated in the Indo-Gangetic plain $\left(36^{0} 54^{\prime} \mathrm{N}\right.$, $\left.25^{\circ} 48^{\prime} \mathrm{E}\right)$ hailing $247 \mathrm{~m}$ above mean sea levelduring Rabi 2015-16 and 2016-17 seasons. Irrigation of field was done prior to sowing against rainfed treatment and sowing was done as per the instructions of package of practices

*Corresponding author: norah-cobsbot@pau.edu 
(Rabi) in randomized block design. The plant height $(\mathrm{cm})$ and biomass accumulation $(\mathrm{g})$ were recorded during the pod initiation. The specific leaf weight indicates the leaf thickness and was determined by the method of Radford (1967). Photosynthetic rate was recorded as $\mu$ mole $\mathrm{CO}_{2} \mathrm{~m}^{-2} \mathrm{~s}^{-1}$ by using Portable Photosynthesis System (LI-6400XT, LICOR).Leaf samples were collected during reproductive phase. Fresh weight was recorded and the leaves were kept in $15 \mathrm{ml}$ distilled water for $24 \mathrm{~h}$ for saturated weight. The saturated leaves were kept in an oven for 72 $\mathrm{h}$ at $80^{\circ} \mathrm{C}$ and dry weight was recorded. The damage in leaves due to moisture stress was elucidated in terms of MPI by the method of Fletcher and Drexlure (1980). Leaf sample (0.1 g) was washed and kept in distilled water for 24 $\mathrm{h}$. The electrical conductivity (EC) was measured using Mettler Toledo, conductivity meter FEP 30. After recording, the same tissue was kept for boiling in water bath for half an hour and after cooling the EC is measured again.

MPI was calculated as:

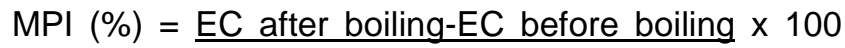
EC after boiling

The effect of moisture stress on cellular respiration of leaves was elucidated by the method of Steponkus and Lamph ear (1967). Cellular respiration in terms of TTC \%reduction= $\left(\mathrm{OD}_{\mathrm{h}} / \mathrm{OD}_{\mathrm{c}}\right) \times 100$ ( $\mathrm{h}=$ heat treated, $\mathrm{c}=$ control)

The pods were collected and percent of filled and unfilled pods was calculated. The pods from wild species were hand-picked from time to time to avoid shattering. Total number of pods and 100 seeds were counted and weight was recorded for all the accessions after harvesting.
Yield of accessions was recorded at maturity. Mean value of chickpea accessions was calculated from three replicates each from both the Rabi trials and calculated values were subjected to SPSS 16.0 software Tukey's post hoc test to test the difference between treatments and accessions. Path coefficient analysis including correlation and polynomial regression coefficients between morphophysiological components and yield attributes were analysed using Microsoft office Excel version 2010. Mean fold/percent increase or decrease data was calculated in rainfed plants against irrigated ones.

\section{RESULTS AND DISCUSSION}

\section{Morpho-Physiological Evaluation}

C judaicum 182 and 185B depicted reduced plant height by 26.1 and $27.4 \%$ in rainfed conditions (Table-1). C pinnatifidum 212 depicted resistance by documenting minimum reduction of $15.3 \%$ under rainfed conditions. Aslam et al. (2015) reported that maize hybrids exhibited drought tolerance at $50 \%$ field capacity by adhering to low decline in plant height. $C$ judaicum 17148 arrayed a decline of only $0.78 \%$ in biomass accumulation under rainfed conditions portraying its desiccation tolerance under rainfed conditions that might be a result of due course of evolution (Table 1). The disruption in remobilization of photosynthates in common bean towards vegetative structures under rainfed conditions has been evidenced by Polaniaet al. (2017).

Table 1: Plant height, biomass accumulation and specific leaf weight of wild chickpea accessions under irrigated and rainfed conditions

\begin{tabular}{|c|c|c|c|c|c|c|}
\hline \multirow[b]{2}{*}{ Wild accessions } & \multicolumn{3}{|c|}{ Irrigated } & \multicolumn{3}{|c|}{ Rainfed } \\
\hline & $\begin{array}{l}\text { *Plant height } \\
\mathrm{cm} \mathrm{pl}^{-1}\end{array}$ & $\begin{array}{c}\text { *Biomass } \\
\text { accumulation g } \\
\text { pl }^{-1}\end{array}$ & SLW $\mathrm{gm}^{-2} \mathrm{pl}^{-1}$ & $\begin{array}{c}\text { *Plant } \\
\text { height } \mathrm{cm} \\
\mathrm{pl}^{-1}\end{array}$ & $\begin{array}{c}{ }^{*} \text { Biomass } \\
\text { accumulation } \\
\mathrm{g} \mathrm{pl}^{-1}\end{array}$ & $\underset{2}{S L \mathrm{pl}^{-1}}$ \\
\hline$C j L$ & 2 & $9.17 \pm 1.60^{a}$ & $2.44 \pm 0.04^{\mathrm{C}}$ & $21.54 \pm 3.24^{a}$ & $8.97 \pm 2.29^{a}$ & 2.06 \\
\hline C judaicum 185 & & 15.37 & 2.8 & $21.83 \pm 0.94^{a}$ & $14.13 \pm 0.54^{a}$ & 2.65 \\
\hline C pinnatifidum 212 & $26 . \varepsilon$ & $14.47 \pm 0.90^{\mathrm{a}}$ & 3.33 & $22.08 \pm 0.46^{a}$ & $7.16 \pm 2.11^{\mathrm{a}}$ & $3.41 \pm 0.16^{\mathrm{a}}$ \\
\hline 17148 & & 8.50 & & 20.6 & 8.43 & \\
\hline$C j L$ & 27.7 & $16.23 \pm 1.11^{\mathrm{a}}$ & $2.37 \pm$ & $24.71 \pm 0.65^{\mathrm{a}}$ & $13.83 \pm 4.15^{\mathrm{a}}$ & $0.08^{\mathrm{C}}$ \\
\hline C judaicum 182 & $29.50 \pm 4.2$ & $10.50 \pm 4.03^{a}$ & $2.37 \pm 0.23^{\mathrm{c}}$ & $21.79 \pm 0.77^{a}$ & $9.23 \pm 0.31^{\mathrm{a}}$ & $2.04 \pm 0.04^{c}$ \\
\hline & 28.06 & 12.37 & 2.68 & 22.10 & 10.29 & 2.44 \\
\hline
\end{tabular}

${ }^{*}$ Non-significant difference. Mean values are represented as \pm S.D. Values marked with same alphabet are non-significant at alpha 0.05 level. Pooled data for Rabi 2015-16 and 2016-17 
There were significant and prominent differences in SLW under irrigated and rainfed conditions in wild accessions (Table 1). Rainfed treatment imposed negative variations in SLW in C judaicum 182 and $C$ judaicum 185B by 13.7 and $15.8 \%$ respectively in comparison to irrigated one. C pinnatifidum212 embarked least decline of $2.5 \%$ under rainfed conditions. The decline in SLW are in corroboration with the reports of Vanaja et al. (2011). Differences in decline of SLW under drought among sunflower cultivars (Canavaret al. 2014) are correlated to differences in photosynthetic capacity, because of the fact that they held strong relationships among the values of water use efficiency, leaf area, total dry weight and relative water content. Wild accession $C$ judaicum 185 reduced its photosynthetic rate by $65.0 \%$ while on the contrary $C$ pinnatifidum212 recorded minimal decline of $18.7 \%$ under rainfed conditions (Table
2). Drought stress portrayed inhibitory effect on the soybeans in the seedling stage through stomatal limitation and thus damaging the photosynthetic system (Wang et al. 2018). C judaicum 17148 and $C$ pinnatifidum212 expressed their tolerance capacities by resisting a minimal change of $4.9 \%$ and $5.4 \%$ in relative water content under rainfed conditions (Table 2). RWC was negatively influenced under drought stress conditions in all the chickpea accessions. This could be attributed to reduction in transpiration via stomata that withheld water in leaves under rainfed conditions. Sunflower variety 'Sanbro' retained high RWC that act as feasible parameter in imparting tolerance under drought conditions. Reduction in the rigidity of leaves occurs on account of changes in the extensibility of the tissue and absorptive capacity of the cell wall (Canavaret al. 2014).

Table 2: Photosynthetic rate (PR) and relative watercontent (RWC) of wild chickpea accessions under irrigated and rainfed conditions

\begin{tabular}{|l|ccc|c|}
\hline \multirow{2}{*}{ Wild accessions } & \multicolumn{2}{|c|}{ Irrigated } & \multicolumn{2}{c|}{ Rainfed } \\
\cline { 2 - 5 } & $\mathrm{PR}\left(\mu \mathrm{molCO} \mathrm{Cm}_{2} \mathrm{~m}^{-2}\right)$ & $\mathrm{RWC}(\%)$ & $\mathrm{PR}\left(\mu \mathrm{molCO} \mathrm{I}_{2} \mathrm{~m}^{-2}\right)$ & $\mathrm{RWC}(\%)$ \\
\hline C judaicum 185B & $5.94 \pm 0.07^{\mathrm{b}}$ & $34.90 \pm 4.10^{\mathrm{b}}$ & $3.45 \pm 0.35^{\mathrm{c}}$ & $30.45 \pm 0.35^{\mathrm{cd}}$ \\
C judaicum 185 & $8.21 \pm 2.47^{\mathrm{b}}$ & $40.50 \pm 0.57^{\mathrm{b}}$ & $2.88 \pm 1.17^{\mathrm{c}}$ & $38.20 \pm 0.71^{\mathrm{b}}$ \\
C pinnatifidum 212 & $14.15 \pm 1.34^{\mathrm{a}}$ & $53.65 \pm 4.31^{\mathrm{a}}$ & $11.50 \pm 1.84^{\mathrm{a}}$ & $50.75 \pm 1.34^{\mathrm{a}}$ \\
C judaicum 17148 & $9.61 \pm 0.48^{\mathrm{ab}}$ & $51.10 \pm 1.70^{\mathrm{a}}$ & $4.90 \pm 1.13^{\mathrm{bc}}$ & $48.55 \pm 0.21^{\mathrm{a}}$ \\
C judaicum 95 & $9.80 \pm 1.27^{\mathrm{ab}}$ & $33.75 \pm 3.89^{\mathrm{b}}$ & $7.95 \pm 1.06^{\mathrm{ab}}$ & $28.95 \pm 1.06^{\mathrm{a}}$ \\
C judaicum 182 & $6.96 \pm 0.55^{\mathrm{b}}$ & $37.20 \pm 1.13^{\mathrm{b}}$ & $4.10 \pm 0.57^{\mathrm{bc}}$ & $32.85 \pm 0.21^{\mathrm{c}}$ \\
Mean & 9.11 & 41.85 & 5.80 & 38.29 \\
\hline
\end{tabular}

Mean values are represented as $\pm S . D$. Values marked with same alphabet are non-significant at alpha 0.05 level. Pooled data for Rabi 2015-16 and 2016-17

Amongst wild accession, $C$ judaicum $185 \mathrm{~B}$ recorded lowest value of $2.1 \%$ membrane damage under rainfed condition. $C$ pinnatifidum212 exhibited maximum decline of $23.3 \%$ of membrane damage under rainfed conditions over irrigated conditions. The response of Sesbania accessions varied significantly depicting an overall low biomass producing Sesbania accessions that were correlated with relatively higher MPI than that of high biomass producing accessions under water deficit conditions. Gunes et al. (2008) successfully screened 11 chickpea cultivars under drought stress conditions using MPI as a reliable physiological indicator. They found that high biomass producing chickpea cultivars were lower in MPI as compared to drought-sensitive cultivars under water stress conditions.
Stress denatures the enzymatic activity and the phenomenon accelerates in direct proportion with the intensity of stress (Figure 1). Similar results were observed in soybean (Ghassemi-Golezani and Lotfi 2012) and winter oil-seed rape (Ghassemi-Golezaniet al. 2010b). Amongst wild accession, $C$ pinnatifidum 212 expressed its tolerance potential by damaging only $6.6 \%$ of the total enzymatic activity under rainfed conditions.

\section{Yield and Yield Attributes}

The pod filling significantly declined under rainfed and irrigated conditions in all the wild chickpea accessions. In wild accession simultaneous pod collection continued to avoid shattering and showed comparatively lesser 

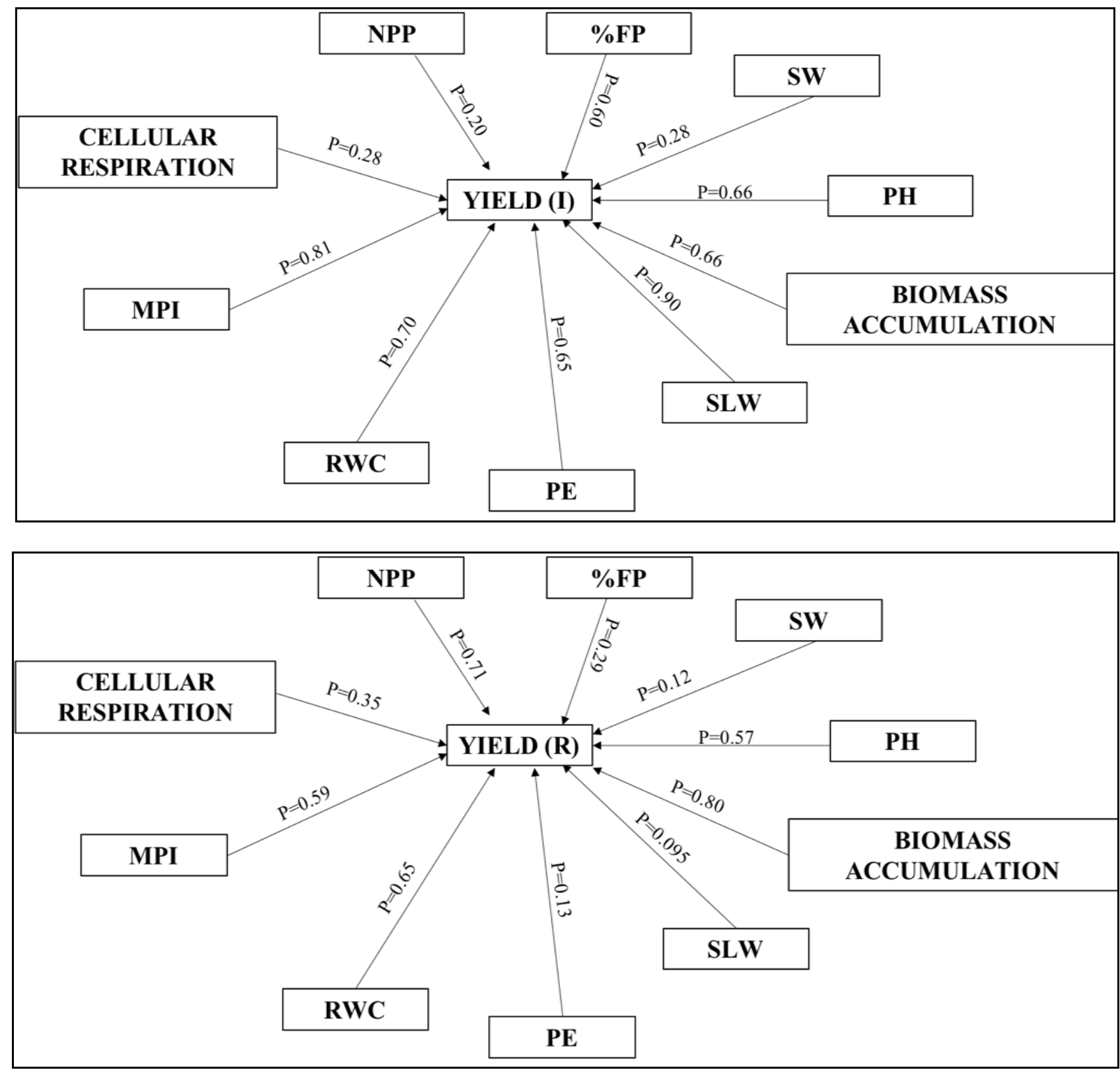

Figure 1: Path coefficient analysis depicting the direct effects of NPP (number of pods per plant), $\%$ FP (percent filled pods), SW (100 seed weight), PH (plant height), biomass accumulation, SLW (specific leaf weight), PE (photosynthetic efficiency), RWC (relative water content), MPI (membrane permeability index) and cellular respiration on yield under irrigated (I) and rainfed (R) conditions

unfilled pods pointing towards their tolerance behaviour. C judaicum 17148 expressed a minimal decline of $2.5 \%$ amongst all accessions under rainfed conditions in comparison to irrigated situations (Table 3). Significant variation in number of pods was noticed among all the accessions under irrigated conditions alike in rainfed irrigations' judaicum 17148 among the wild accession was least $(4.1 \%)$ affected under rainfed conditions. However, on the contrary, $C$ judaicum 95 did not exploit its potential to avoid rainfed condition by reducing the number of pod/plant by $46.2 \%$. Wild accession $C$ judaicum 95 emerged as a sensitive accession by recording $0.55 \mathrm{~g}$ decline in 100 seed weight. The tolerance capacity was reflected in wild accession $C$ pinnatifidum212 $(0.50 \mathrm{~g})$ that possessed lowest reduction in 100 seed weight under rainfed condition. Results depicting declining 100 seed weight were reported in chickpea (Ceyhan et al. 2012) and Glycine max (Ghassemi- Golezani and Lotfi 2012). 

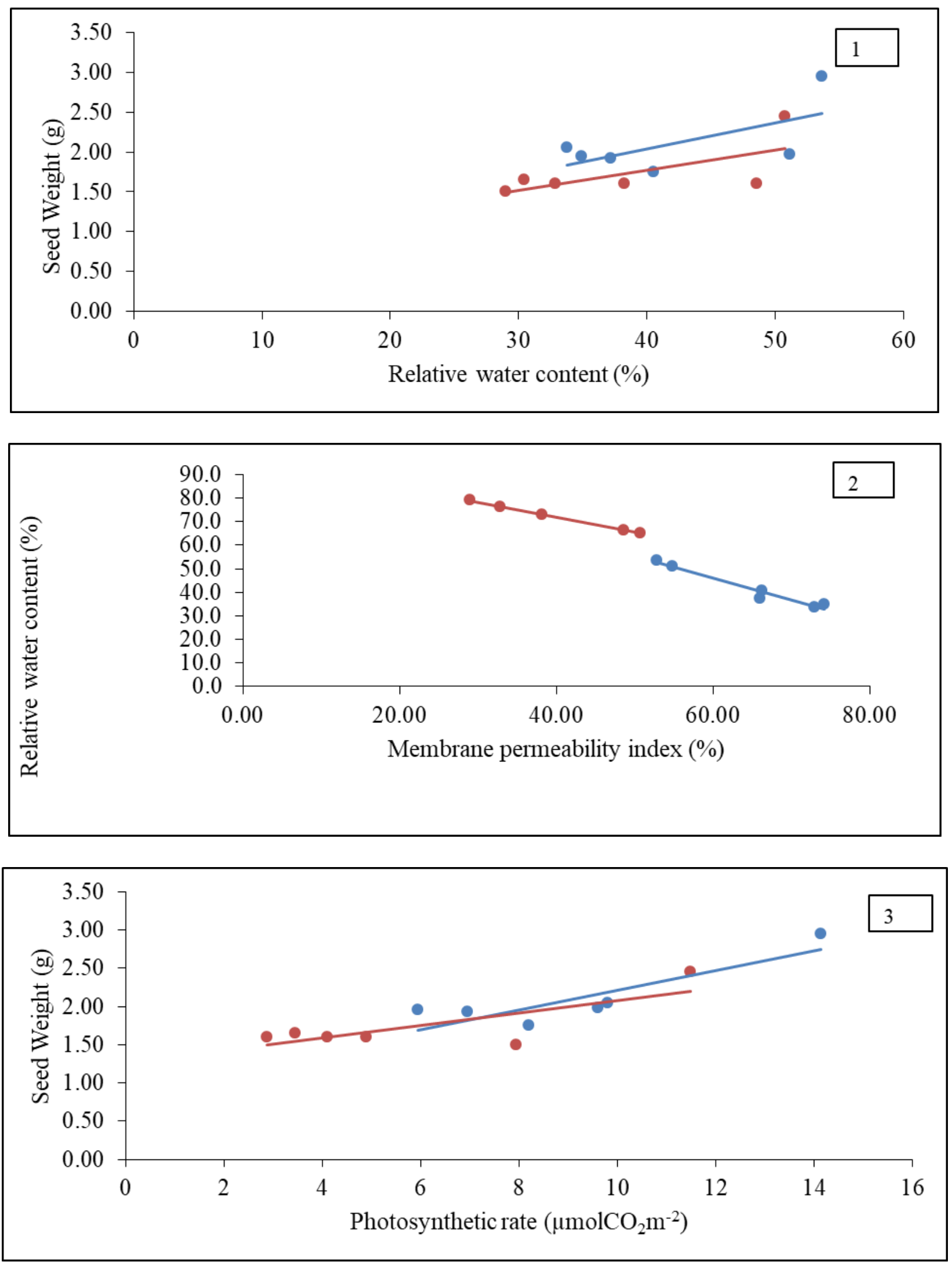

Figure 2.Pearson's correlation (linear) between 1) seed weight and relative water content 2) relative water content and membrane permeability index 3) seed weight and photosynthetic rate under irrigated (blue trendline) and rainfed (orange trendline) conditions 
Table 3: Percent filled pods, number of pods, 100 seed weight and yield of wild chickpea accessions under irrigated and rainfed conditions

\begin{tabular}{|c|c|c|c|c|c|c|c|c|}
\hline \multirow[b]{2}{*}{ Wild accessions } & \multicolumn{4}{|c|}{ Irrigated } & \multicolumn{4}{|c|}{ Rainfed } \\
\hline & $\begin{array}{c}\text { \%filled } \\
\text { podspl }^{-1}\end{array}$ & Pods $\mathrm{pl}^{-1}$ & $\begin{array}{l}{ }^{*} 100 \text { seed } \\
\text { weight }(\mathrm{g})\end{array}$ & Yield $_{1} \mathrm{~g} \mathrm{pl}^{-}$ & $\begin{array}{c}\text { \%filled } \\
\text { podspl }^{-1}\end{array}$ & ${ }^{*}$ Pods $\mathrm{pl}^{-1}$ & $\begin{array}{l}{ }^{*} 100 \text { seed } \\
\text { weight }(\mathrm{g})\end{array}$ & $\begin{array}{c}\text { *Yield } \\
\mathrm{pl}^{-1}\end{array}$ \\
\hline $\begin{array}{ll}C & \text { judaicum } \\
185 B & \end{array}$ & $\begin{array}{c}81.49 \\
\pm 1.04^{\mathrm{ab}}\end{array}$ & $\begin{array}{c}29.50 \\
\pm 0.50^{\text {ab }}\end{array}$ & $\begin{array}{r}1.95 \\
\pm 0.05^{\mathrm{a}}\end{array}$ & $\begin{aligned} & 24.38 \\
& \pm 2.88^{\mathrm{ab}}\end{aligned}$ & $\begin{array}{l}79.48 \\
\pm 0.32^{\mathrm{a}}\end{array}$ & $\begin{array}{l}26.31 \\
\pm 6.35^{\mathrm{a}}\end{array}$ & $\begin{array}{r}1.65 \\
\pm 0.05^{a}\end{array}$ & $\begin{array}{r}17.06 \\
\pm 0.89^{\mathrm{a}}\end{array}$ \\
\hline C judaicum 185 & $\begin{array}{c}79.14 \\
\pm 1.55^{\mathrm{ab}}\end{array}$ & $\begin{array}{r}21.82 \\
\pm 2.85^{\mathrm{b}}\end{array}$ & $\begin{array}{r}1.75 \\
\pm 0.35^{\mathrm{a}}\end{array}$ & $\begin{array}{r}18.35 \\
\pm 3.41^{\mathrm{ab}}\end{array}$ & $\begin{array}{r}75.52 \\
\pm 2.07^{\mathrm{ab}}\end{array}$ & $\begin{array}{l}20.93 \\
\pm 0.07^{\mathrm{a}}\end{array}$ & $\begin{array}{r}1.60 \\
\pm 0.20^{\mathrm{a}}\end{array}$ & $\begin{array}{r}15.04 \\
\pm 1.72^{\mathrm{a}}\end{array}$ \\
\hline $\begin{array}{l}\text { C pinnatifidum } \\
212\end{array}$ & $\begin{array}{l}86.76 \\
\pm 1.11^{\mathrm{a}}\end{array}$ & $\begin{array}{r}24.04 \\
\pm 2.63^{\mathrm{b}}\end{array}$ & $\begin{array}{r}2.95 \\
\pm 0.15^{a}\end{array}$ & $\begin{array}{l}29.49 \\
\pm 1.49^{\mathrm{a}}\end{array}$ & $\begin{array}{l}79.97 \\
\pm 0.07^{\mathrm{a}}\end{array}$ & $\begin{array}{l}16.16 \\
\pm 0.85^{\mathrm{a}}\end{array}$ & $\begin{array}{r}2.45 \\
\pm 0.35^{\text {a }}\end{array}$ & $\begin{array}{l}20.35 \\
\pm 0.38^{\mathrm{a}}\end{array}$ \\
\hline $\begin{array}{l}C \\
17148\end{array}$ & $\begin{array}{l}77.20 \\
\pm 0.40^{\mathrm{b}}\end{array}$ & $\begin{array}{r}19.55 \\
\pm 0.55^{b}\end{array}$ & $\begin{aligned} & 1.98 \\
\pm & 0.27^{a}\end{aligned}$ & $\begin{array}{r}18.23 \\
\pm 3.36^{b}\end{array}$ & $\begin{array}{c}71.10 \\
\pm 1.20^{\mathrm{b}}\end{array}$ & $\begin{array}{c}10.52 \\
\pm 1.52^{\mathrm{a}}\end{array}$ & $\begin{aligned} & 1.60 \\
\pm & 0.01^{\text {a }}\end{aligned}$ & $\begin{array}{c}12.84 \\
\pm 1.96^{\mathrm{a}}\end{array}$ \\
\hline C judaicum 95 & $\begin{array}{r}75.84 \\
\pm 2.72^{b}\end{array}$ & $\begin{array}{r}40.10 \\
\pm 4.90^{\mathrm{a}}\end{array}$ & $\begin{array}{c}2.05 \\
\pm 0.25^{\mathrm{a}}\end{array}$ & $\begin{array}{l}28.28 \\
\pm 0.9^{\mathrm{ab}}\end{array}$ & $\begin{array}{r}69.39 \\
\pm 0.51^{\mathrm{b}}\end{array}$ & $\begin{array}{l}23.56 \\
\pm 3.77^{\mathrm{a}}\end{array}$ & $\begin{array}{c}1.50 \\
\pm 0.20^{\mathrm{a}}\end{array}$ & $\begin{array}{r}16.38 \\
\pm 0.08^{\mathrm{a}}\end{array}$ \\
\hline C judaicum 182 & $\begin{array}{l}77.86 \\
\pm 1.41^{\mathrm{b}}\end{array}$ & $\begin{array}{c}28.49 \\
\pm 0.84^{\text {ab }}\end{array}$ & $\begin{array}{r}1.93 \\
\pm 0.23^{\mathrm{a}}\end{array}$ & $\begin{array}{r}30.03 \\
\pm 1.79^{b}\end{array}$ & $\begin{array}{c}75.12 \\
\pm 1.69^{\mathrm{ab}}\end{array}$ & $\begin{array}{l}20.32 \\
\pm 2.68^{a}\end{array}$ & $\begin{array}{r}1.60 \\
\pm 0.20^{\mathrm{a}}\end{array}$ & $\begin{array}{l}11.19 \\
\pm 0.88^{\mathrm{a}}\end{array}$ \\
\hline Mean & 79.71 & 27.25 & 2.10 & 24.79 & 75.10 & 19.63 & 1.73 & 15.48 \\
\hline
\end{tabular}

${ }^{\bar{*}}$ Non-significant difference. Mean values are represented as $\pm S$.D. Values marked with same alphabet are non-significant at alpha 0.05 level. Pooled data for Rabi 2015-16 and 2016-17

The final yield of plant was compromised in all the accessions under rainfed conditions. Wild accession $C$ judaicum 95 also reunited in line by deciphering reduction of $62.7 \%$ under rainfed conditions. C judaicum 17148 (29.5\%) and $C$ pinnatifidum212 (30.9\%) were comparatively less affected under rainfed treatments in comparison to irrigated conditions. Terminal drought stress induced severe reduction in pod filling in sensitive chickpea genotypes that hypothesized that availability of water is mandatory during seed filling (ZamanAllah et al. 2011).

\section{Path coefficient and correlation analysis}

Path coefficient analysis evaluated the input of morpho-physiological parameters and yield parameters on final yield under irrigated and rainfed conditions. The parameters contributing towards the final yield at significant level are plant height, biomass accumulation and relative water content under irrigated $(P=0.66$, $\mathrm{P}=0.66, \mathrm{P}=0.70)$ and rainfed $(\mathrm{P}=0.57, \mathrm{P}=0.80$, $P=0.65$ ) conditions respectively (Figure 1$)$. The overall morphological health during the tenure undermining water scarcity especially at flower initiation to pod filling stage determines the final yield. This is further proved by the values of strong negative correlation of membrane damage with relative water content under irrigated $(r=-0.97)$ and rainfed $(r=-0.98)$ conditions. Wild accessions resisted membrane damage under water scarce situations and thus protecting photosynthetic apparatus and maintaining appreciable yields and maintaining relative water content. Seed weight, a yield component, also depicted a significant negative correlation with membrane damage under rainfed conditions concluding an inversely proportional relationship $(r=-0.69)$.

In conclusion wild accessions Cjudaicum 17148 and $C$ pinnatifidum212 resisted water scarcity by lowering membrane damage and maintaining high relative water content and thusgiving high seed weight and final yield under rainfed conditions.

\section{ACKNOWLEDGEMENT}

The authors are thankful to University Grant Commission, New Delhi, for providing financial assistance to conduct the research work. 


\section{REFERENCES}

Ahsan, M. S., Kumar, M., Upadhyay, J. P., Hussain, M. A., Gupta, P. K. and Singh, A. (2018)Effect of different doses of Trichoderma harzianum and fungicides for the management of collar rot of chickpea caused by Sclerotium rolfsii. International Journal of Pure and Applied Bioscience 6:1656-1660.

Aslam, M., Zamir, M. S. I., Anjum, S. A., Khan, I. and Tanveer, M. (2015). An Investigation into morphological and physiological approaches to screen maize (Zea mays L.) hybrids for drought tolerance. Cereal Research Communications 43: 41-51.

Canavar, Ö., Götz, K. P., Ellmer, F., Chmielewski, F. M. and Kaynak, M. A. (2014). Determination of the relationship between water use efficiency, carbon isotope discrimination and proline in sunflower genotypes under drought stress. Australian Journal of Crop Science 8: 232-42.

Ceyhan, E., Kahraman, A., Ates, M. K. and Karadas,S. (2012). Stability Analysis on seed yield and its components in peas. Bulgarian Journal of Agricultural Science18:905-911.

Fletcher, R. A. and Drexlure, D. M. (1980). Interactions of dichloro-methyl and 2,4-D in cultivated oats (Avena sativa). Weed Science 28: 363-366.

Ghassemi-Golezani, K. and Lotfi, R. (2012). Response of soybean cultivars to water stress at reproductive stages. International Journal of Plant, Animal and Environmental Sciences 2:198-202.

Ghassemi-Golezani, K., Khomari, S., Dalil, B., Hosseinzadeh-Mahootchy, A. and Chadordooz-Jeddi, A. (2010). Effects of seed aging on field performance of winter oilseed rape. JournalofFood, Agriculture and Environment 8:175-178.

Gunes, A., Inal, A., Adak, M. S., Bagci, E. G., Cicek, N. and Eraslan, F. (2008). Effect of drought stress implemented at pre- or post- anthesis stage some physiological as screening criteria in chickpea cultivars.

Russian Journal of Plant Physiology 55: 59-67.

Hamidou, F., Halilou, O. and Vadez, V. (2013). Assessment of groundnut under combined heat and drought stress.Journal of Agronomy and Crop Science199: 1-11.

Polania, J., Rao, I. M., Cajiao, C., Grajales, M., Rivera, M., Velasquez, F., Raatz, B. and Beebe, S. E. (2017). Shoot and root traits contribute to drought resistance in recombinant inbred lines of MD 23-24 * SEA 5 of common bean. New Phytologist 8: 1-18.

Radford, D. J. (1967). Growth analysis formulae: their use and abuse. Crop Science 7: 171-175. .

Steponkus, P. L. and Lamphear, F. O. (1967). Refinement of the triphenyl tetrazolium chloride method of determining cold injury. Plant Physiology 42: 1423-1426.

Vanaja, M., Yadav, S. K., Archana, G., JyothiLakshmi, N., Ram Reddy, P. R., Vagheera, P., Abdul-Razak, S. K., Maheswari, M. and Venkateswarlu, B. (2011). Response of C4 (maize) and C3 (sunflower) crop plants to drought stress and enhanced carbon dioxide concentration. Plant Soil Environment 57: 207-215.

Wang, Y., Li, Y., Wu, H., Hu, B., Zheng, J., Zhai, H., Lv, S., Liu, X., Chen, X., Qiu, H., Yang, J., Zong, C., Han, D., Wen, Z., Wang, D. and Xia, Z. (2018) Genotyping of soybean cultivars with medium-density array reveals the population structure and QTNs underlying maturity and seed traits. Frontiers in Plant Science 9:doi: 10.3389/fpls.2018.00610.

Zaman-Allah, M., Jenkinson, D. and Vadez, V. (2011). A conservative pattern of water use, rather than deep or profuse rooting, is critical for the terminal drought tolerance of chickpea. Journal of Experimental Botany 62: 4239-4252. 